\title{
ANALYSIS OF CYCLICAL BEHAVIOR OF FISCAL POLICY THROUGH FISCAL REACTION FUNCTION: THE CASE OF TURKEY*
}

\author{
Süleyman KASAL ${ }^{1}$
}

\begin{abstract}
To analyze of cyclical behavior of fiscal policy provides important information about the direction and outcomes of fiscal policy. The cyclical behavior of fiscal policy is basically two-way. First is procyclical fiscal policy, second is countercyclical fiscal policy. One way to analyze cyclical behavior of fiscal policy is to estimate the fiscal reaction function for country. This study examine to what type of exhibit cyclical behavior of fiscal policy for in period 2000Q1-2015Q4 for Turkey. It is concluded that primary balance showed a positive response to the output gap. Accordingly, it is concluded that fiscal policyis "countercyclical" for this sample. In other words, it can be said that fiscal policy has been a role in reducing the severity of cyclical fluctuations. Even though fiscal policy appearsto has been responsible, as a new evidence about debt sustainability it is also found that fiscal fatigue may occur in very high debt levels Accordingly, fiscal policy implementations should be conduct within the framework of public fiscal discipline.
\end{abstract}

Keywords: Fiscal reaction function, countercyclical fiscal policy, procyclical fiscal policy, fiscal fatigue.

JEL Code: E62, H62, H63.

\section{Introduction}

The investigation of cyclical behavior of fiscal policy is an important issue for understanding economic interactions. In fact, policies should be implemented based on these interactions. Keynesian models argue for an increase in public spending for economic recovery during recession while Barro (1979) suggests that fiscal policy should be neutral. Within the framework of these views discussions on the academic field have begun to focus on how the fiscal policies have affected the severity of cyclical fluctuations and the role of fiscal policies has become an important issue. In addition the issue of whether fiscal policies are sustainable or not has found their place in the axis of these discussions.

The main objective of this study is to analyze what type of exhibit cyclical behavior of fiscal policyin period 2000Q1-2015Q4 for Turkey. The results indicate that fiscal policy iscountercyclical in this period. Another result of the analysis is that very high debt level may lead to fiscal fatigue. Indeed the emergence of such a symptom may raise concerns about the sustainability of fiscal policies. Therefore, priority should be given to the implementation of policies that do not impair public fiscal discipline.

\footnotetext{
* This paper was created by using master's thesis that titled "Fiscal Space and Fiscal Rule" was prepared by Res. Asst. Suleyman Kasal in consultancy with Assoc. Prof. Ozay Ozpence at Pamukkale University Soical Sciences Institute on $07 / 04 / 2017$.

1 Res. Asst., Anadolu Unıversity, Department of Public Finance, skasal@anadolu.edu.tr
} 


\section{The Cyclical Behavior of Fiscal Policy}

When cyclical behavior of fiscal policy is mentioned, two basic concepts emerge. The first is procyclical fiscal policy and the second is countercyclical fiscal policy. Sticky prices and wages in Keynesian theory prevent price adjustments to occur immediately in demand fluctuations. The countercyclical fiscal policy helps the economy to adapt to such fluctuations more rapidly and fully. For this reason, fiscal policy should reduce the fluctuations in business cycles actively by reducing taxes and increasing expenditures in bad times of economy (Halland \& Bleaney, 2009: 1). The countercyclical fiscal policy also includes low public spending and high tax rates when the economy is in good time. However, the procyclical fiscal policy is acting in an expanding direction in times when the economy is good (Kaminskyet. al., 2005: 17). There are many reasons why the fiscal policy is procyclical. However, among the main reasons; limits on access to national and international credit markets, institutional and political structures, and the polarization of preferences regarding social inequality (Halland \& Bleaney, 2009: 4). Furthermore, Tornell\& Lane (2008) found that the increase in revenues as the reason of the procyclical behavior of fiscal policy is "voracity effect" in which politicians want to more spending increase (Fatas \& Mihov, 2012: 4). Frankel et. al. (2012) showed that one-third of developing countries have been able to get out of procyclical fiscal policies bias in the last 10 years and have countercylical fiscal policy behavior. The main reason for this was increased financial integration and low output volatility. However, they suggested that increasing the quality of institutions as very important issue was a more valid reason.

The fiscal space also has an impact on the cyclical behavior of fiscal policy. Because the stock of public debt may limit the resources that can maintain countercyclical fiscal policy. In addition, even if resources are available, high public debt can send a negative signal to creditors and taxpayers, causing the country to remain in a difficult position in the future (Abdih et. al.; 2010: 13).

\section{Literature}

In the literature, it is seen that the cyclical behavior of the fiscal policies is different in developed and developing countries. In this context, firstly Gavin and Perotti (1997) gave an answer as to what is the cyclical behavior of fiscal policies. They have argued that the fiscal policies in Latin American countries areexpansionary in good times, while they arecontractionary in bad times. In other words, Gavin and Perotti (1997) have shown that fiscal policies are procyclical in Latin American countries. In developing countries, there are studies suggesting that fiscal policy is mostly procyclical. However, studies on developed countries appear to have countercyclical fiscal policy or, at worst, an acyclical fiscal policy. For instance, Alesina, et. al. (2008), Fatas \& Mihov (2012), Egert (2012), Combes et. al. (2017) found that developed countries have countercyclical fiscal policy.

\section{Results}

In this study, fiscal reaction function is estimated for analysis of cyclical behavior of fiscal policyfor Turkey. The aim is to show how fiscal policy have behaved in Turkey. The fiscal reaction function is a rule that helps fiscal policy makers for predict how to respond to macroeconomic variables (Nguyen, 2013: 3). When the fiscal reaction function is well modeled and analyzed, accurate results can be obtained. According to findings, It is observed that the response of the primary balance to the output gap is positive; in other words, the fiscal policy is countercyclical unlike other developing countries. Therefore, it can be said that fiscal policyhas been a role in 
reducing the severity of cyclical fluctuations.In addition, it can be also said that public fiscal discipline has contributed to fiscal credibility. Other result is fiscal fatigue which is a stricter debt sustainability conditionas suggested Ghosh et. al. (2013). This situation constitutes an obstacle to fiscal policy as a stabilization tool. In other words, fiscal policy may increase the severity of cyclical fluctuations at very high debt levels. Therefore, debt policies should be implemented in a way that will not harm public fiscal discipline.

\section{Conclusion}

In recent years, many studies have been carried out in order to see how the fiscal policies are in cyclical behavior. In the studies, it has been investigated by using various methodshow the fiscal policies in the country or country groups are in a cyclical behavior. This study analyzes the cyclical behavior of fiscal policy for Turkey. As a result, it is found that fiscal policy is countercyclical. This result shows that fiscal policy has an important role in achieving economic stability in Turkey. Also strong public financehas fundemantal role with the Transition Program to Strong Economy which is implemented after the 2001 crisis. It has also resulted that signs of fiscal fatigue may reveal in very high debt levels. Therefore, debt policies need to be implemented carefully. In fact, high budget deficits can create high debt as it had been experienced in the past and this situation may lead to heavy economic burden and harm to public fiscal discipline. When the two results are evaluated together, fiscal policy implementations should be realized within the framework of public fiscal discipline. For this, implementation of a fiscal rule that can act as an anchor can be an important policy.

\section{References}

Abdih, Y., Lopez-Murphy, P., Roitman, A.\& Sahay, R. (2010). The Cyclicality of Fiscal Policy in the Middle East and Central Asia:Is the Current Crisis Different?.IMF Working Papers, No. 10-68.

Aghion, P. (2008). Cyclical Budgetary Policy and Economic Growth: What Do We Learn from OECD Panel Data? In M. Acemoglu, Daron; Rogoff Kenneth; Woodford (Ed.), NBER Macroeconomics Annual 2007, Vol. 22, pp. 251-278. University of Chicago Press.

Alesina, A., Tabellini, G., \& Campante, F. R. (2008). Why is Fiscal Policy Often Procyclical? Journal of the Economic Association, 6(September 2008), 1006-1036.

Barro, R. J. (1979). On the Determination of the Public Debt. Journal of Political Economy, 87(5), 940-971.

Combes, J. L., Minea, A., \& Sow, M. (2017). Is fiscal policy always counter- (pro-) cyclical? The role of public debt and fiscal rules. Economic Modelling, 65(September 2016), 138-146.

Égert, B. (2010). Fiscal policy reaction to the cycle in the OECD: pro- or counter-cyclical? OECD Economics Department Working Papers. Vol. 19-763.

Fatás, A., \& Mihov, I. (2012). Fiscal policy as a stabilization tool. TheB.E. Journal of Macroeconomics, $12(3)$

Frankel, J. A. ., Vegh, C. A., \& Vuletin, G. (2012). On Graduation from Fiscal ProcyclicalityFaculty Research Working Paper Series No. April 2012. 
Gavin, M. \& Perotti, R. (1997). Fiscal Policy in Latin America. In Bernanke, Ben S.; Rotemberg, J. (Ed.), NBER Macroeconomics Annual 1997, Vol. 12, pp. 11-72. MIT Press.

Ghosh, A. R., Kim, J. I., Mendoza, E. G., Ostry, J. D., \& Qureshi, M. S. (2013). Fiscal Fatigue, Fiscal Space and Debt Sustainability in Advanced Economies. The Economic Journal, 123(Şubat), 4-30.

Havard, H.\& Bleaney, M. (2011). Explaining the procyclicality of fiscal policy in developing countriesCREDIT Research Paper, No. 11/09, The University of Nottingham, Centre for Research in Economic Development and International Trade (CREDIT), Nottingham.

Kaminsky, G. L., Reinhart, C. M. \& Vegh, C. A. (2005). When It Rains, It Pours : Procyclical Capital Flows and Macroeconomic Policies. In K. Getler, Mark; Rogoff (Ed.), NBER Macroeconomics Annual 2004, Vol. 19, pp. 11-82. MIT Press.

Nguyen, T. (2013). Estimating India's Fiscal Reaction Function. ASARC Working Paper 2013/05.

Woo, J. (2008). Why Do More Polarized Countries Run More Pro-cyclical Fiscal Policy ? Woo, Jaejoon. 2009. Review of Economics and Statistics, 91(4), 850-870. 